\title{
Development of a rapid method for quantitative evaluation of Mycobacterium tuberculosis growth based on competitive polymerase chain reaction
}

\author{
M. LIGOZZI, E. PELOSI and R. FONTANA \\ Institute of Microbiology, University of Verona, Verona, Italy
}

\begin{abstract}
A competitive polymerase chain reaction (CPCR) assay for the quantitative evaluation of Mycobacterium tuberculosis growth was developed based on co-amplification of genomic DNA and a modified DNA fragment derived from a well-conserved region of the $16 \mathrm{~S}$ rRNA gene. There was a good correlation between the number of DNA copies in the sample, indicated by competitive PCR, and the number of colony forming units determined by conventional culture methods.
\end{abstract}

\section{Introduction}

Quantitative evaluation of growth is an essential tool in diagnostic microbiology, in studies on the pathogenesis of bacterial diseases and in antimicrobial drug efficacy testing. Procedures based on culture techniques are the most sensitive and specific; unfortunately, they do not provide rapid results when applied to quantification of slow-growing bacteria such as Mycobacterium tuberculosis.

Competitive polymerase chain reaction (cPCR)-based assays have been proposed in recent years for quantitative detection of micro-organisms. In such procedures a range of concentrations of a modified PCR product and target DNA bearing the same primer recognition sequences are co-amplified in the same tube. The resulting products must be clearly distinguishable by gel electrophoresis analysis, in order to allow densitometric comparison of the relative intensities of the bands for both DNA species. The point at which modified DNA and target DNA give the same amount of products is determined and defines the concentration in the test sample. cPCR has been applied to the direct detection and quantification of $M$. tuberculosis in clinical samples [1-3]. These assays are based on the insertion element IS6110, which is specific for strains belonging to the $M$. tuberculosis complex.

In the present study a quantitative assay for myco-

Received 12 June 1997; revised version accepted 5 Feb. 1998.

Corresponding author: Professor R. Fontana. bacterial growth based on cPCR was developed. In this assay a modified DNA fragment derived from a well conserved region of the $16 \mathrm{~S}$ rRNA gene, which is present as one copy per chromosome in slow growing mycobacteria [4-6], is co-amplified with wild-type DNA. This method was shown to give results comparable with those obtained with conventional culture-based determination of the number of colony forming units (cfu), and provided a result at least 2 weeks earlier than culture.

\section{Materials and methods}

\section{Bacterial strain and DNA preparation}

M. tuberculosis clinical isolates (identified to species level by standard biochemical methods [7]) were used in this study and were grown in Middlebrook $7 \mathrm{H}-9$ medium (Difco) at $37^{\circ} \mathrm{C}$ in air for $10-14$ days until a turbidity equal to that of no. 1 McFarland standard $\left(\cong 1 \times 10^{8} \mathrm{cfu} / \mathrm{ml}\right)$ was reached. For DNA preparation, cells from $1 \mathrm{ml}$ of culture were harvested and washed in $10 \mathrm{mM}$ Tris, $1 \mathrm{mM}$ EDTA (TE) buffer. The pellet was resuspended in $1 \mathrm{ml}$ of $10 \mathrm{mM}$ Tris, $10 \mathrm{~mm}$ EDTA, Tween $80 \quad 0.1 \%$ and heat-inactivated at $80^{\circ} \mathrm{C}$ for $30 \mathrm{~min}$. Samples were pelleted again and the cells were resuspended in $85 \mu \mathrm{l}$ of the same buffer containing lysozyme (Boehringer $\mathrm{GmbH}$, Mannheim, Germany) $2 \mathrm{mg} / \mathrm{ml}$. After incubation for $1 \mathrm{~h}$ at $37^{\circ} \mathrm{C}, 10 \mu \mathrm{l}$ of SDS $1 \%$ and $5 \mu \mathrm{l}$ of proteinase $\mathrm{K} 1 \mathrm{mg} / \mathrm{ml}$ were added to each sample and the suspension was incubated again for $1 \mathrm{~h}$ at $37^{\circ} \mathrm{C}$. After centrifugation at $11000 \mathrm{~g}$ for $10 \mathrm{~min}$ at $4^{\circ} \mathrm{C}$, the supernate was transferred to another tube and used as a source of DNA in the amplification reaction. The final volume of extracted DNA was $100 \mu 1$. 


\section{Synthesis of competitor DNA}

Published 16S rRNA gene sequences from various mycobacterial species [4-6] were examined for regions of sequence conservation from which oligonucleotides suitable for quantitative analysis of growth of the highest possible number of species with the same primer pair and competitor DNA could be designed. A suitable region was identified from nucleotide 979 to nucleotide 1099 of the $16 \mathrm{~S}$ rRNA gene coding region of $M$. tuberculosis (EMBL Data Library accession number X58890) and the following primers were designed: MT1 (5'GGGTTTGACATGCACAGGACGCGTCTAG, positions 979-1006), MT2 (5'GCGCTCGTTGCGGGACTTAACCCAACAT, positions 10721099) and MT1D (5'CATGCACAGGACGCGTCTAGGGCCTGTGTGCAGGTGGTGCA, positions $987-$ 1045 with an 18-base deletion from position 1007 to 1024). Competitor DNA was prepared by amplification of M. tuberculosis VR16 (a clinical isolate from our collection) DNA with the MT1D-MT2 primer pair, thus yielding a deleted version of the original 16S rRNA gene sequence. Amplification was carried out in a total volume of $100 \mu \mathrm{l}$ of standard PCR buffer with $1.5 \mathrm{mM}$ $\mathrm{MgCl}_{2}$ (Perkin Elmer Cetus), containing $0.2 \mathrm{mM}$ (each) deoxynucleoside triphosphate, $100 \mathrm{pmol}$ (each) primer (MT1D and MT2) and $1 \mu \mathrm{g}$ of $M$. tuberculosis DNA. After denaturation for $10 \mathrm{~min}$ at $94^{\circ} \mathrm{C}$ and the addition of $2.5 \mathrm{U}$ of Taq DNA polymerase (Perkin Elmer Cetus), 30 thermal cycles (automatic cycler from Violet, Rome, Italy) were carried out as follows: denaturation at $94^{\circ} \mathrm{C}$ for $1 \mathrm{~min}$, primer annealing at $60^{\circ} \mathrm{C}$ for $2 \mathrm{~min}$ and extension at $72^{\circ} \mathrm{C}$ for $6 \mathrm{~min}$. The amplification products were quantified by measuring the $A_{260}$ with an LKB Biochrom Ultrospec II spectrophotometer (Pharmacia Inc., Italy), assuming an $A_{260}$ of 1 corresponds to a concentration of $50 \mu \mathrm{g}$ of DNA $/ \mathrm{ml}$. This estimation was also confirmed by end-point dilution amplification. This was performed by diluting the amplification products in triplicate and amplifying $2 \mu \mathrm{l}$ of each dilution. The dilution end-point was defined as the greatest dilution that gave detectable amplification products in a PCR assay. The Poisson distribution of positive samples showed that the sensitivity was 1 molecule.

\section{CPCR}

The $\mathrm{cPCR}$ assay was performed initially with DNA from the VR16 strain and its own derived competitor DNA. Subsequently, wild-type DNA from other strains (10 clinical isolates from our collection) was tested. DNA was extracted from triplicate samples $(1 \mathrm{ml} / \mathrm{sam}$ ple) of a culture in Middlebrook 7H-9 medium which was adjusted to no. $1 \mathrm{McFarland}$ turbidity. For each sample four parallel reactions were performed, each of which contained the MT1 and MT2 primer pair, $2 \mu 1$ of wild-type DNA and decreasing copy numbers of competitor DNA molecules $\left(10^{7}-10^{4}\right)$. Amplification was carried out as described above in a $100 \mu \mathrm{l}$ final volume. After amplification, $10 \mu \mathrm{l}$ of the mixture were electrophoresed on ethidium bromide $(0.5 \mu \mathrm{g} / \mathrm{ml})$ containing agarose (FMC, BioProducts, Rockland, ME, USA) $3 \%$ gels or acrylamide $6 \%$ gels in TBE buffer ( $45 \mathrm{mM}$ Tris, $45 \mathrm{mM}$ boric acid, $1 \mathrm{mM}$ EDTA) and visualised by UV transillumination. Pictures were taken with a Polaroid camera and the intensity of the DNA bands on the photograph were measured with an Epson GT 9000 optical scanner. Peak areas of both amplified products were calculated by the public domain ImageCalc, a Microsof ${ }^{\mathrm{R}}$ Windows ${ }^{\mathrm{TM}}$-based computer programme [8]. The deleted DNA area (DA) was corrected (DAc) for its lower molar ethidium bromide incorporation as follows: $\mathrm{DAc}=\mathrm{DA} \times$ (wild-type length/deleted length) $=\mathrm{DA} \times 1.17$. The regression curve was calculated by plotting the DAc/wild-type DNA area (WA) ratio on the $Y$ axis against the competitor DNA copy number on the $X$ axis. The copy number of the wild-type target sequence was calculated from the curve expression for $y=1$.

\section{Determination of $c f u$}

Samples $(100 \mu \mathrm{l})$ of $10^{-2}-10^{-5}$ dilutions of the cultures were placed into $7 \mathrm{H}-10$ medium contained in a plastic quadrant of a four-quadrant plate. Plates were allowed to dry and placed in individual $\mathrm{CO}_{2}$-permeable polyethylene bags at $37^{\circ} \mathrm{C}$ in $\mathrm{CO}_{2} 5-10 \%$. After $2-4$ weeks colonies were counted and the number of cfu was determined.

\section{Isoniazid susceptibility testing}

A $100-\mu 1$ volume of a $M$. tuberculosis VR16 culture adjusted to no. 1 McFarland turbidity was diluted 1 in 1000 in Middlebrook 7H-9 medium containing isoniazid at 0.2 and $1 \mu \mathrm{g} / \mathrm{ml}$. The number of DNA copies and cfu were determined in 1-ml samples taken at 0,2 and 4 days. The same competitor copy number range $\left(10^{4}-10^{8}\right)$ was used in all the cPCR susceptibility assays.

\section{Results and discussion}

Comparison experiments were performed between the cPCR assay and cfu determination. Fig. 1 (inset) illustrates a representative determination of the DNA copy number of the bacterial suspension. It is clear that increasing the copy number of the competitor DNA (lower band) progressively competed with the wild-type DNA sequence (upper band). A regression curve was obtained by comparing the DAc/WA ratio with the copy number of the competitor DNA. The equivalence point was calculated according to the regression curve and the value of $1.4 \times 10^{6}$ (corresponding to $7 \times 10^{7}$ copies $/ \mathrm{ml}$ of the starting cell suspension) was assigned to the wild-type copy number. The average copy number obtained from the three determinations was $6.5(\mathrm{SD} 0.5) \times 10^{7}$. Three determinations of $\mathrm{cfu} / \mathrm{ml}$ of 


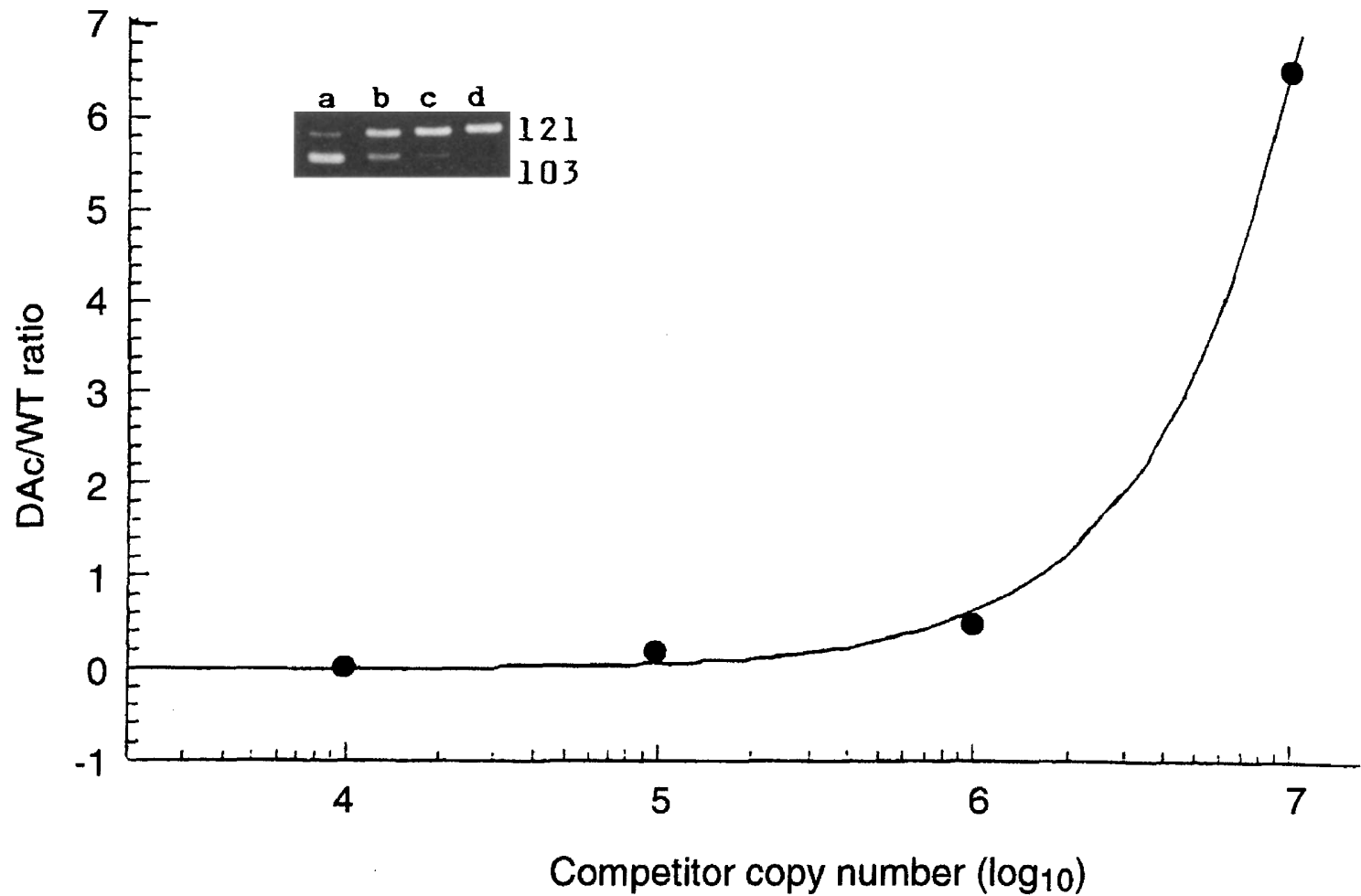

Fig. 1. Inset: representative determination of $M$. tuberculosis VR16 DNA copy number by competitive PCR. Constant amounts of wild-type DNA (upper band) were co-amplified with decreasing amounts of competitor DNA (lower band), as described in the text. a, $1 \times 10^{7} ; \mathbf{b}, 1 \times 10^{6} ; \mathbf{c}, 1 \times 10^{5} ; \mathbf{d}, 1 \times 10^{4}$. Polaroid pictures of the gel were scanned and peak areas of both amplified products were quantified in each lane. The regression curve (main picture) was calculated by plotting the DAc/WA ratio against the competitor copy number, as follows: $y=0.0049+0.0000069 \times(\mathrm{R}=0.999)$. At the equivalence point $(\mathrm{y}=1)$, a DNA copy number of $1.4 \times 10^{6}$ was found by interpolation; this represented the number of wild-type DNA copies present in $20 \mu \mathrm{l}$ of the original cell suspension.

the same bacterial suspension yielded a mean value of 7.9 (SD 0.3) $\times 10^{7}$. The same comparison experiments were made with 10 additional clinical isolates of $M$. tuberculosis from our collection. The cPCR results were plotted against cfu determination and a regression line calculated with $\mathrm{y}=7.2 \times 10^{6}+0.99 \mathrm{x}$ (data not shown). A value of $r=0.947$ was obtained, indicating a good correlation between the two methods. In general, cPCR gave higher values than cfu determinations (from 3 to $25 \%$ higher).

As an example of the possible applications of the cPCR assay, evaluation of $M$. tuberculosis growth was performed in the presence or absence of isoniazid (INH, 0.2 and $1 \mu \mathrm{g} / \mathrm{ml}$ ). As shown in Fig. 2 and Table 1, after incubation for 2 days, the DNA copy number of both the INH-containing samples was nearly $1 \log _{10}$ lower than that of the control at time 0 and $>2 \log _{10}$ lower after incubation for 4 days. As compared with the control at time 0 , the decrease in cfu was $90 \%$ (INH, $0.2 \mu \mathrm{g} / \mathrm{ml}$ ) and $92 \%$ (INH, $1 \mu \mathrm{g} / \mathrm{ml}$ ) after 2 days; 95\% (INH, $0.2 \mu \mathrm{g} / \mathrm{ml}$ ) and $98 \%(\mathrm{INH}, 1 \mu \mathrm{g} / \mathrm{ml})$ after 4 days. The inhibitory effect of INH was detected visually in broth cultures after incubation for 8 days; colonies were detected after 16 days.

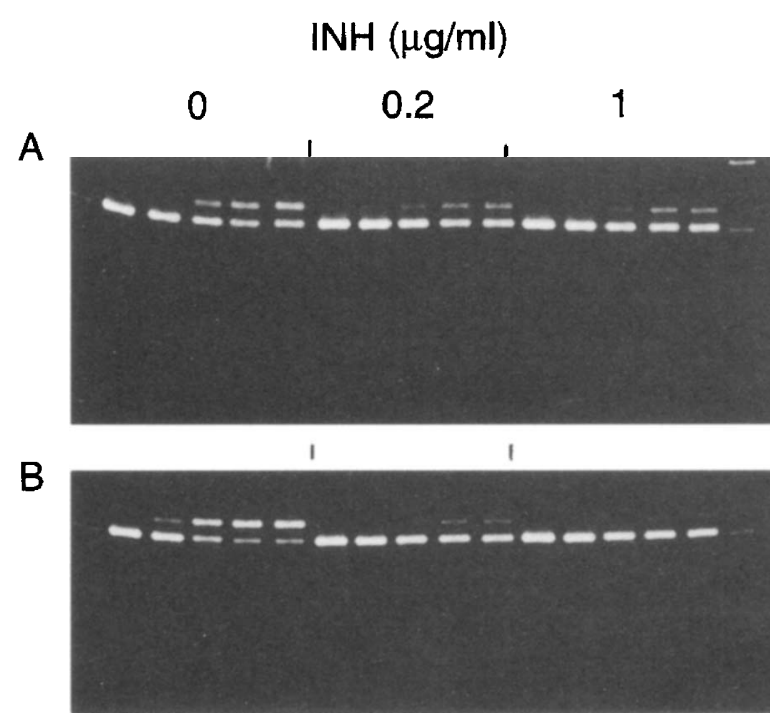

$a b c d e a b c d e a b c d e$

Fig. 2. Co-amplification of constant amounts of $M$. tuberculosis DNA from cultures incubated in the presence or absence of isoniazid (INH) for 2 (A) and 4 (B) days with decreasing amounts of competitor DNA. Competitor copy number: a, $1 \times 10^{8} ; \mathbf{b}, 1 \times 10^{7}$; c, $1 \times 10^{6} ;$ d, $1 \times 10^{5} ;$ e, $1 \times 10^{4}$. First and last lanes: $\phi \times 174$ RF DNA/Hae III DNA marker (Gibco BRL). 
Table 1. Determination of $\mathrm{cfu}$ and DNA copies/ml of $M$. tuberculosis VR16 cultures incubated in the presence or absence of isoniazid

\begin{tabular}{|c|c|c|c|c|c|c|}
\hline \multirow{2}{*}{$\begin{array}{l}\text { Time } \\
\text { (days) }\end{array}$} & \multicolumn{2}{|c|}{ Control } & \multicolumn{2}{|c|}{ Isoniazid $(0.2 \mu \mathrm{g} / \mathrm{ml})$} & \multicolumn{2}{|c|}{ Isoniazid $(1 \mu \mathrm{g} / \mathrm{ml})$} \\
\hline & $\mathrm{cfu} / \mathrm{ml}$ & DNA copies/ml & $\mathrm{cfu} / \mathrm{ml}$ & DNA copies/ml & $\mathrm{cfu} / \mathrm{ml}$ & DNA copies $/ \mathrm{ml}$ \\
\hline 0 & $2 \times 10^{5}$ & $1 \times 10^{5}$ & $1 \times 10^{5}$ & $8 \times 10^{4}$ & $1 \times 10^{5}$ & $8 \times 10^{4}$ \\
\hline 2 & $8 \times 10^{5}$ & $5 \times 10^{5}$ & $1 \times 10^{4}$ & $<10^{4}$ & $8 \times 10^{3}$ & $<10^{4}$ \\
\hline 4 & $3 \times 10^{7}$ & $2 \times 10^{7}$ & $5 \times 10^{3}$ & $<10^{4}$ & $2 \times 10^{3}$ & $<10^{4}$ \\
\hline
\end{tabular}

cPCR was performed with $2 \mu \mathrm{l}$ of DNA corresponding to $20 \mu \mathrm{l}$ of the original cell suspension. The number of DNA copies contained in $1 \mathrm{ml}$ of the original cell suspension was obtained by multiplying by 50 the number of copies calculated by the cPCR assay.

In conclusion, the cPCR assay described here is a suitable method for the rapid monitoring of $M$. tuberculosis growth and, for the development of rapid susceptibility assays, constitutes a promising approach warranting further investigation. An advantage over the IS6110-based cPCR $[1-3]$ is that the $16 \mathrm{~S}$ rRNAbased cPCR is likely to work with mycobacteria other than $M$. tuberculosis.

We thank Dr T.H. van Kuppevelt for providing the ImageCalc program and Dr G. Cornaglia for processing the scan data. This work was supported by Istituto Superiore di Sanità, $1^{\circ}$ Progetto Nazionale Tubercolosi, 1995.

\section{References}

1. Chevrier D, Rasmussen SR, Guesdon JL. PCR product quantification by non-radioactive hybridization procedures using an oligonucleotide covalently bound to microwells. Mol Cell Probes 1993; 7: 187-197.

2. Kolk AHJ, Noordhoek GT, De Leeuw O, Kuijper S, van Embden JDA. Mycobacterium smegmatis strain for detection of Myco- bacterium tuberculosis by PCR used as internal control for inhibition of amplification and for quantification of bacteria. $J$ Clin Microbiol 1994; 32: 1354-1356.

3. An Q, Buxton D, Hendricks A et al. Comparison of amplified Q beta replicase and PCR assays for detection of Mycobacterium tuberculosis. J Clin Microbiol 1995; 33: 860-867.

4. Boddinghaus $\mathrm{B}$, Rogall $\mathrm{T}$, Flohr $\mathrm{T}$, Blöcker $\mathrm{H}$, Böttger EC. Detection and identification of mycobacteria by amplification of rRNA. J Clin Microbiol 1990; 28: 1751-1759.

5. Edwards U, Rogall $T$, Blöcker $H$, Emde $M$, Böttger EC. Isolation and direct complete nucleotide determination of entire genes. Characterization of a gene coding for $16 \mathrm{~S}$ ribosomal RNA. Nucleic Acids Res 1989; 17: 7843-7852.

6. Kempsell KE, Ji Y, Estrada-G ICE, Colston MJ, Cox RA. The nucleotide sequence of the promoter, 16S rRNA and spacer region of the ribosomal RNA operon of Mycobacterium tuberculosis and comparison with Mycobacterium leprae precursor rRNA. J Gen Microbiol 1992; 138: 1717-1727.

7. Nolte FS, Metchock B. Mycobacterium. In: Murray PR, Baron EJ, Pfaller MA, Tenover FC, Yolken RH (eds) Manual of clinical microbiology, 6th edn. Washington, DC, American Society for Microbiology. 1997: 400-437.

8. van de Lest CHA, Veerkamp $\mathrm{JH}$, van Kuppevelt $\mathrm{TH}$. ImageCalc: a Microsoft ${ }^{\mathrm{R}}$ Windows ${ }^{\mathrm{TM}}$ application for quantitative image analysis and comparison. Biotechniques 1995; 18: $1050-1055$. 